that its functions will be retained in some form.

At one stage, it was widely rumoured that the science adviser would be made part of a policy planning unit in the White House and that OSTP would be scrapped as a separate entity. Such a plan was in fact under consideration by the team which planned the reorganisation, but the team changed its mind and recommended that OSTP be retained. "They came to us as dis. believers but walked away believers", one OSTP official remarked last week.

Though the change of mind may have been brought about by the quality of OSTP's contributions to Presidential decision-making (the explanation offered by OSTP officials), an equally important factor is that OSTP has powerful support from the scientific community and from some influential members of Congress. When President Nixon scrapped the former Office of Science Policy, his action was greeted with a cry of alarm from a number of prominent scientists, including a committee of the National Academy of Sciences. A similar outpouring of wrath would have been certain if Carter had tried to eliminate OSTP. He would also have faced resistance from Congress-which would have to approve such a plan-and in particular from Senator Edward Kennedy, who was the chiref sponsor of the legislation which established OSTP.

Similar considerations also led to the reprieve of the Council on Environmental Quality (CEQ), an agency in the Executive Office which is required to monitor compliance by other government agencies with the National Environmental Policy Act, and to provide advice to the President on long-term environmental issues. The reorganisation team was seriously considering scrapping CEQ or at least stripping it of some of its major responsibilities, but when those possibilities were leaked early in July, a hue and cry arose from environmentalists. CEQ has long been regarded as a powerful counterweight to federal agencies which conduct large public works or energy programmes likely to affect the environment, and potential demise would have been regarded as a serious blow to the environmental movement, many of whose leaders were quick to remind Carter that they had helped elect him.

In the end, CEQ will be retained, though its staff will be reduced from 40 to 32 , and it will continue to monitor envirommental impact statements filed by other government agencies.

By preserving CEQ and OSTP, the reorganisation plan has by-passed two potential sources of trouble in Congress, and the plan should be approved without too much of a fight.

\title{
Breeder: far from dead?
}

President Carter's plans to deter the use of plutonium as a reactor fuel worldwide received a setback last week when the Senate voted to keep the controversial Clinch River Breeder Reactor alive. The move, which came after several hours of intense debate, will not necessarily derail Carter's policy completely, however, for the Senate at least agreed that the project should be deferred for a year, and the House of Representatives has yet to act on the matter. Nevertheless, the vote is being regarded by antinuclear groups as a serious blow.

The Clinch River plant is intended to be a demonstration liquid metal fast breeder reactor, designed to test the commercial feasibility of the fast breeder design. Once expected to cost less than $\$ 1,000$ million and to be in operation by the late 1970 s, its estimated cost has soared to more than $\$ 2,000$ million and its expected completion date has slipped to at least 1983.

In April, as part of his nuclear nonproliferation policy, Carter proposed that the plant be cancelled and that the entire fast breeder reactor programme should be turned into a longterm R\&D effort. Since the chief purpose of the Clinch River plant was to hasten the commercial introduction of fast breeder reactors, Carter argued that it no longer fits in with his nuclear strategy. The Administration's plan essentially rests on the assumption that the nuclear power programme will grow much more slowly than once anticipated; uranium supplies will thus be adequate to fuel light water reactors for several decades, and breeder reactors will not be required to augment fuel supplies by producing plutonium.

The move to downgrade the breeder reactor programme was coupled with another move away from the use of plutonium in the United States. Carter also announced that the United States would defer indefinitely the reprocessing of spent reactor fuel to ne-

$$
\begin{aligned}
& \text { Sorry, for copyright } \\
& \text { reasons some images } \\
& \text { on this page may not } \\
& \text { be available online }
\end{aligned}
$$

Carter: breeder setback cover plutonium and recycle it as a reactor fuel. The announcements were designed to bolster the Administration's attempts to dissuadie ather countries from entering the plutonium economy, the argument being that the United States could not credibly argue against the use of plutonium without renouncing such use itself.

Although those assumptions were swiftly and sharply challenged by the nuclear industry, until recently it seemed that Carter's plan would be approved by Congress. Fierce lobbying by the nuclear industry and its supporters has, however, produced results.

The first indication that the Clinch River plant may be reprieved came last month when the House Committee on Science and Technology voted to authorise the full $\$ 150$ million for the project next year, an amount which would allow construction to begin and the plant to be put back on schedule. The House has yet to act on the committee's recommendation, however.

The next move came in the Senate Commitee on Energy and Natural Resources, when supporters of the project, led by Senators Frank Church and Henry Jackson, also proposed that the Clinch River plant should be given $\$ 150$ million. The committee split 8-8 on the proposal. Church and Jackson then proposed a compromise measure: $\$ 75$ million should be budgeted for the plant, but construction should be deferred for a year. The rationale, essentially, was that the Carter Administration should use the year's delay to try to persuade other countries not to build their own breeder reactors; if the persuasion failed, the $\mathrm{Clinch}$ River project should be given the gneen light. The committee again split 8-8 on the proposal. Last week, however, after two days of debate, the Senate approved the compromise ChurchJackson proposal by a vote of 49 to 38.

Attention is now being focused on the House, which is expected to take up the mater next week. Though the Science and Technology Committee has proposed giving the Clinch River plant he full $\$ 150$ million, a compromise proposal along the lines of the Church-Jackson amendment is gु expected to be offered. Lobbying on both sides is fience, but at this stage few people are willing to predict the outcome.

Colin Norman 